K. G. AKBULUT ${ }^{1}$, S. GUNEY' , F. CETIN ${ }^{1}$, H. N. AKGUN²,

S. H. AKTAS ${ }^{2}$, and H. AKBULUT ${ }^{2}$

\title{
MELATONIN DELAYS BRAIN AGING BY DECREASING THE NITRIC OXIDE LEVEL
}

\author{
Received November 12, 2012.
}

\begin{abstract}
Aging is believed to be a first-order risk factor for most neurodegenerative disorders. The neuronal cell loss that occurs with aging has been partly attributed to increased production of nitric oxide and high caspase activity. Melatonin (MLT) might have a role in the regulation of nitric oxide in the brain. We investigated the effects of MLT on the nitrite/nitrate levels and caspase- 3 enzyme activity in the frontal cortex, temporal cortex, and hippocampus of young and aged rats. There was no significant difference between the nitrite levels in the frontal cortex and hippocampus of young and aged animals. In the temporal cortex of aged rats, the nitrite level, however, was significantly higher $(P<0.001)$. In the aged group, MLT significantly decreased these levels in the brain regions. Caspase- 3 enzyme activity in the temporal and frontal cortices was significantly higher in aged rats when compared to the control group $(P<0.05)$. Melatonin did not cause significant changes in caspase-3 activity in any brain region of both young and aged rats. Thus, brain regions demonstrate different caspase- 3 enzyme activities and nitrite levels in the aging process. Exogenous MLT administration might delay brain aging (by moderation of death of neurons and glia) via decreasing the nitrite level.
\end{abstract}

Keywords: aging, caspase-3, melatonin, nitric oxide, temporal cortex, frontal cortex, hippocampus.

\section{INTRODUCTION}

Aging is one of the risk factors for the neurodegenerative diseases [1]. Recently, it was reported that aging is accompanied by the development of some inflammatory processes at the tissue level in different parts of the body and in the brain in particular [2]. Aging intemsifies the glial cell activity in the brain [3], and the number of abnormal astrocytes increases with aging [4]. The increased apoptotic cell death of astrocytes observed in neurodegenerative diseases, such as Alzheimer's disease, is consistent with these findings [5]. Likewise, increased activity of caspase-3 and caspase- 9 involved in the process of apoptosis

\footnotetext{
${ }^{1}$ Gazi University School of Medicine, Department of Physiology, Ankara, Turkey.

${ }^{2}$ Ankara University School of Medicine, Department of Medical Oncology, Ankara, Turkey.

Correspondence should be addressed to

K. G. Akbulut (e-mail: kgakbulut@yahoo.com),

S. Guney (e-mail: sguney@gazi.edu.tr),

F. Cetin (e-mail: ferihan.cetin@izmir.edu.tr),

H. N. Akgun (e-mail: akgun.hnalan@hotmail.com),

S. H. Aktas (e-mail: handeenfez@yahoo.com),or

H. Akbulut (e-mail: akbulut@medicine.ankara.edu.tr).
}

has been reported in neurodegenerative disorders, like Alzheimer's, Parkinson's, and Huntington's disease $[6,7]$.

The existence of nitric oxide synthase (NOS)containing neurons in the cerebral cortex, cerebellum, hippocampus, and hypothalamus suggests a possible role of nitric oxide (NO) in the oxidative-antioxidative processes, apoptosis, and aging of the brain $[8,9]$. Nitric oxide can behave either as a free-radical precursor or an antioxidant and neuroprotective agent [10]. Depending on its local concentration and cell type, NO can be an agent promoting either apoptosis or cell survival. Inhibition/induction of apoptosis by NO is mediated by downstream caspases, including caspase-3 [11].

Reactive oxygen and nitrogen species (ROSs and RONs), potent inducers of oxidative damage, have been shown to trigger apoptosis [12]. Accordingly, antioxidant treatment was shown to decrease the rate of this process [13]. Superoxide and hydroxyl radicals and NO might also be related to aging and, in particular, aging-related loss of cognitive functions in humans [14]. 
Melatonin (MLT) demonstrates a wide range of actions in different parts of the body, including effects on the circadian rhythm and neuroendocrine or immune functions [15-17]. Melatonin and its metabolites are potent radical scavengers protecting cells from damage induced by a variety of oxidants, including hydroxyl radicals and lipid peroxidation products [18, 19]. Melatonin was also reported to suppress increased caspase activity in the liver in a rat aging model [20]. Likewise, it was shown that MLT prevents spontaneous neuronal apoptosis by inhibiting downstream targets of Akt, GSK3b, and FOXO-1 [15]. In our study, we aimed to investigate changes in the nitrate levels and caspase- 3 activity in different brain regions of young and aged rats and the effects of MLT on these parameters.

\section{METHODS}

Animal Groups and Tissue Homogenization. A total of 43 young (4-month-old) and aged (14-monthold) male Wistar albino rats was used in this study. The rats were divided into the control group (10 animals in the young subgroup and 10 ones in the aged one) and the melatonin group (10 animals in the young subgroup and 13 ones in the aged subgroup). While rats of the control group were given $0.1 \mathrm{ml}$ of phosphate-buffered saline containing $1 \%$ ethanol, the others (melatonin group) were injected subcutaneously with MLT (Sigma SM 5250, USA) at a dose of $10 \mathrm{mg} / \mathrm{kg}$ per day dissolved in $0.1 \mathrm{ml}$ of phosphate-buffered saline containing $1 \%$ ethanol for 7 days. A maximum of four animals were kept per cage, under conditions of equal periods of light and dark $(12 / 12 \mathrm{~h})$ in a room with lighting control (lights on at 08.00 and off at 20.00). Injections were given daily at $18.00,2 \mathrm{~h}$ before the light was switched off, to compensate a presumed hormone deficiency in aged animals. On the 7 th day of the experiment, the rats were sacrificed at 10.00, and brain tissues were removed and dissected on ice. Tissue samples from the frontal cortex, temporal cortex, and hippocampus were kept in a liquid nitrogen tank until analysis.

The samples were then homogenized in $200 \mu \mathrm{l}$ of a cell lysis buffer (Promega, USA) using a tissue homogenizer (Heidolph Diax 900, Germany). The homogenate was centrifuged at $16,000 \mathrm{rpm}$ for $15 \mathrm{~min}$ at $4^{\circ} \mathrm{C}$, and protein concentrations in the cleared extracts were measured prior to storage at $-86^{\circ} \mathrm{C}$. Cleared extracts of the tissue homogenates were assayed for caspase-3 activity.

Measurement of Caspase-3 Activity. In this study, we used the estimates of caspase-3 activity as an indicator of caspase-dependent apoptosis. The caspase-3 activity was determined by a colorimetric assay kit (Promega, USA) using acetyl-Asp-Glu-ValAsp-p-nitroanilide (pNA) as the substrate. From 25 to $100 \mu \mathrm{g}$ of total protein of the clear extracts of brain tissue were used for the assay. The specific caspase activity was expressed as picomoles yielding pNA per microgram of protein of the supernatant of tissue homogenates [21].

Measurement of the Total Nitrite Levels in the Brain Regions. The nitrite levels were measured using an enzyme-linked immunosorbent assay reader by vanadium chloride ( $\mathrm{VCl3}$ )/Griess assay. Prior to nitrite determination, tissues were homogenized in five volumes of phosphate-buffered saline $(\mathrm{pH}=7.5)$ and centrifuged at $2,000 \mathrm{~g}$ for $5 \mathrm{~min}$. Then, $0.25 \mathrm{ml}$ of $0.3 \mathrm{~N} \mathrm{NaOH}$ was added to $0.5 \mathrm{ml}$ of the supernatant. After incubation for $5 \mathrm{~min}$ at room temperature, $0.25 \mathrm{ml}$ of $5 \%(\mathrm{w} / \mathrm{v}) \quad \mathrm{ZnSO}_{4}$ was added for deproteinization. This mixture was then centrifuged at $3,000 \mathrm{~g}$ for $20 \mathrm{~min}$, and supernatants were used for the assays [22].

Statistical Analysis. Differences among the results obtained in the test groups were compared by one-way ANOVA and the Mann-Whitney U test. The Spearman's test was used for nonparametric correlation analysis. Differences with two-sided $P<0.05$ were considered to be significant.

\section{RESULTS}

Exogenous MLT Decreases the Nitrite Level in the Cerebral Cortex. There were significant differences between the nitrite levels in different brain regions of young and aged rats. The nitrite level in the frontal cortex was significantly higher than that in the temporal cortex and hippocampus of young rats $(P=0.014$ and $P<0.001$, respectively). Likewise, the nitrite levels in the cortical regions (frontal and temporal cortices) in the aged group were higher than those in the hippocampus $(P=0.043$ and $P<$ 0.001 , respectively). No significant differences in the above levels were found in the frontal cortex and hippocampal region with respect to age. However, the nitrite level in the temporal cortex was significantly higher compared to that in the young one $(P<0.001)$ (Fig. 1, Table 1). 


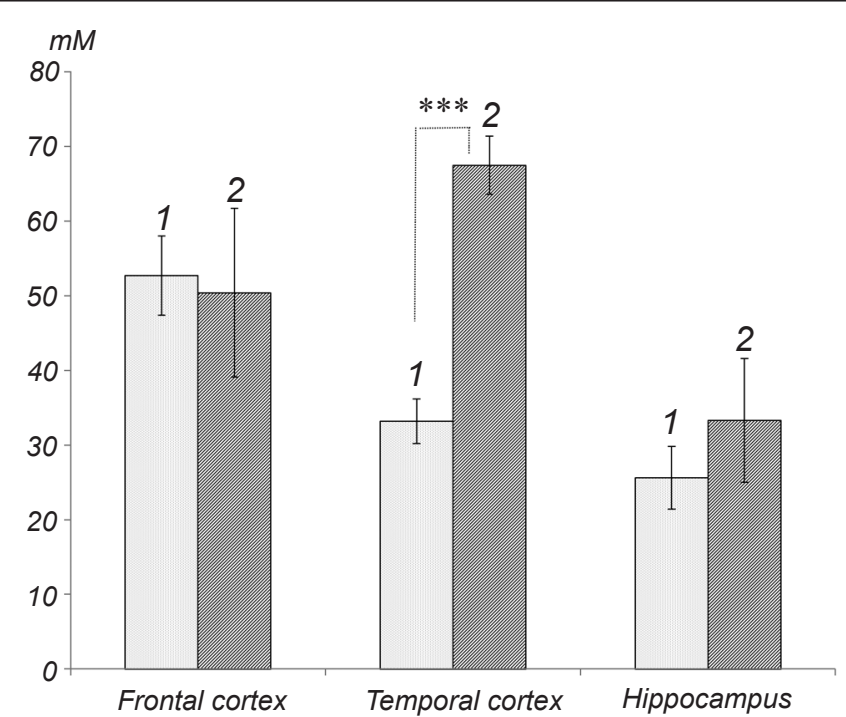

Fig. 1. Nitrite/nitrate levels in different brain regions of control (untreated) groups of young (1) and aged (2) rats. *** Significant difference with $P<0.001$.

Рис. 1. Рівні нітритів/нітратів в різних ділянках мозку контрольних молодих (1) та старих (2) щурів.

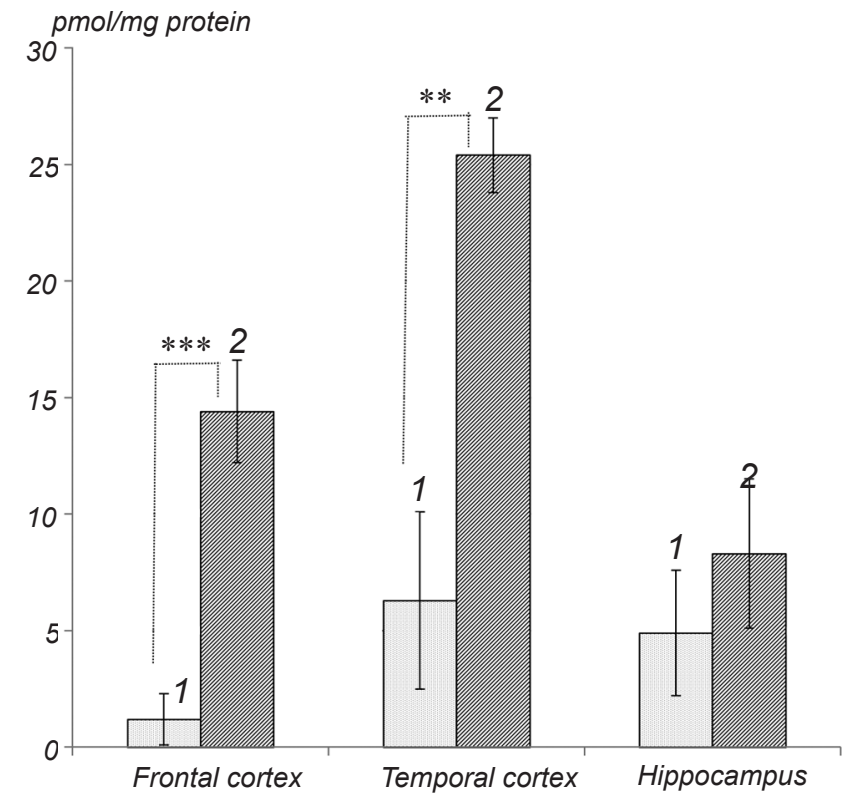

Fig. 2. Caspase-3 activity in control young (1) and aged (2) rats. ${ }^{* *}$ Significant difference with $P=0.010 ;{ }^{* * *}$ the same with $P<0.002$. Рис. 2. Активність каспази-3 в різних ділянках мозку контрольних молодих (1) та старих (2) щурів.

TABLE 1. Nitrite/Nitrate Levels $(\mu M)$ in Different Brain Regions of Assigned Rat Groups

Т а б л и ц я 1. Рівні нітратів/нітритів (мкМ) у різних ділянках мозку щурів досліджених груп

\begin{tabular}{l|c|c|c|c|c|c|}
\hline \multirow{2}{*}{ Brain regions } & \multicolumn{2}{|c|}{ Young rats } & \multirow{2}{*}{$P$} & \multicolumn{2}{|c|}{ Aged rats } & \multicolumn{2}{c}{$P$} \\
\cline { 2 - 3 } & control & melatonin & & control & melatonin & $15.3 \pm 2.9$ \\
\hline Frontal cortex & $52.7 \pm 5.3$ & $45.0 \pm 3.8$ & 0.323 & $50.4 \pm 11.3$ & $<.001$ \\
Temporal cortex & $33.2 \pm 3.0$ & $23.0 \pm 3.2$ & 0.221 & $67.5 \pm 3.9$ & $30.8 \pm 6.1$ & $<0.001$ \\
Hippocampus & $25.6 \pm 4.2$ & $15.0 \pm 2.2$ & 0.152 & $33.3 \pm 8.3$ & $22.1 \pm 2.9$ & 0.116 \\
\hline
\end{tabular}

Footnote. Means \pm s.e.m. are shown.

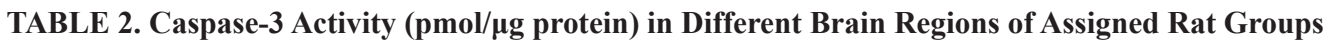

Т а б л и ц я 2. Активність каспази-3 (пмоль/мкг протеїну) у різних ділянках мозку щурів досліджених груп

\begin{tabular}{|c|c|c|c|c|c|c|}
\hline \multirow{2}{*}{ Brain regions } & \multicolumn{2}{|c|}{ Young } & \multirow{2}{*}{$P$} & \multicolumn{2}{|c|}{ Aged } & \multirow{2}{*}{$P$} \\
\hline & control & melatonin & & control & melatonin & \\
\hline Frontal cortex & $1.2 \pm 1.1$ & $3.6 \pm 2.1$ & 0.620 & $14.4 \pm 2.2$ & $12.8 \pm 0.9$ & 0.764 \\
\hline Temporal cortex & $6.3 \pm 3.8$ & $7.1 \pm 2.8$ & 0.877 & $25.4 \pm 1.6$ & $26.6 \pm 5.9$ & 0.829 \\
\hline Hippocampus & $4.96 \pm 2.7$ & $5.7 \pm 2.5$ & 0.866 & $8.3 \pm 3.2$ & $4.9 \pm 1.1$ & 0.465 \\
\hline
\end{tabular}

Footnote. Means \pm s.e.m. are shown.

Exogenous MLT caused insignificant decreases in the nitrite levels in young rats. Short-term MLT treatment significantly decreased the nitrite level in cortical regions of aged rats, while a decrease in the hippocampus was noticeable but not significant (Table 1).

Exogenous MLT and Caspase Activity in the Brain. We found that the levels of caspase-3 activity in the frontal cortex, temporal cortex, and hippocampus were close to each other in young rats (Fig. 2, Table 2). Though not significant, the enzyme activity in the frontal cortex was the lowest among the studied brain regions in the young group. However, the caspase- 3 activity in the temporal cortex was significantly higher than that in the frontal cortex and hippocampus in the aged group $(P=0.05$ and $P=0.03$, respectively; Fig. 2).

The age-related increase in caspase- 3 activity in 
the frontal cortex was more prominent than that in the temporal cortex ( $>10$ times and about 4 times, respectively). There was also a slight insignificant increase in the caspase- 3 activity in the hippocampus with aging (Table 2, Fig.2).

Short-term treatment with exogenous MLT caused no significant changes in caspase-3 activity within different brain regions. Likewise, no significant change in the levels of caspase-3 activity in the cortical regions and hippocampus of the aged group was found after such treatment (Table 2).

The relationship between nitrite levels and caspase-3 activity was different in the control groups of young and aged rats. While there was a considerable, though statistically insignificant $(\rho=-0.398 ; P=0.083)$, trend toward negative correlation between the nitrite and caspase- 3 activity in the young group, the analogous correlation was positive in the aged group $(\rho=0.315$; $P=0.253$ ).

\section{DISCUSSION}

There is an increased incidence of abnormal astrocytes during aging. Agents such as IL-1 and NO produced by those abnormal astrocytes could be partly responsible for general neuronal cell loss [23]. The microglial cell activity is increased in both neurodegenerative diseases and aging [24]. Reactive glial cells may intensify the oxidative damage in the brain. Activated glial cells lead to a more intense formation of ROSs, NO, and peroxynitrite-derived radicals [25]. Oxidative stress induces cognitive and motor deterioration by initiating inflammatory processes in the brain during aging [26]. Siles et al. [27] reported that different NOS activities in the cerebral cortex and cerebellum are age-dependent.

The reports on the level of NO and NOS activity during aging are contradictory [28-30]. Liu et al. [30] found that an increased eNOS activity was observed in the hippocampus and dentate gyrus with aging, but changes in the areas $C A 1$ and $C A 3$ were mild. Likewise, Blanco et al. [31] observed no age-related difference in the nitrite level in the cerebellum. In our study, we found that the nitrite level in the temporal cortex increases with aging, but this was not the case in the frontal cortex and hippocampus (Fig. 2). The microglial activity in the temporal lobe was reported to increase with aging, which is associated with neuronal loss in the temporal cortex and a cognitive function decrease $[32,33]$. Accordingly, an increased pro-oxidant cytokine production in mouse brain tissues induced by lipopolysaccharides was found during aging [34].

Melatonin, the chief secretory product of the epiphysis (pineal gland) is an efficient free-radical scavenger in the body and brain. By preventing oxidative damage, MLT reduces the intensity of apoptosis of neurons and glial cells [35]. In our experiments, we found that short-term exogenous MLT treatment significantly decreases the nitrite levels in the cortical regions but not in the hippocampus of aged rats (Table 1).

Increased apoptosis in various tissues of the body is one of the hallmarks of the aging process. Earlier, we and others found that caspase activity in the liver, lungs, spleen, and gastric mucosa increased with aging [36, 37]. As well, increased caspase-3 activity in cortical regions of the brain during aging was shown previously [38]. The caspase-3 activity in the hippocampus was reported to increase significantly in old individuals when compared to that in young ones [23]. We, however, could not find a significant increase in the caspase- 3 activity in the hippocampus with aging (Table 2). Instead, we found significant increases in the enzyme activity in the cerebral cortices in the current study.

Melatonin has been shown to inhibit caspase-3 activity and JNK-mediated cell death of neurons induced by the action of a neurotoxin [39]. We showed earlier that 1 -week-long treatment with MLT decreased the caspase-3 level in the gastrointestinal system [36]. In our study, however, we found that short-term (1 week) introduction of exogenous MLT exerted no significant effect on the increased caspase- 3 activity in the brain regions of aged rats. The discordance of the effects of MLT on nitrite levels and caspase- 3 activity in the brain might be related to the short-term action of the drug (1 week). Therefore, testing of the effects of prolonged administration of MLT on caspase activity in brain tissues would be a subject of another study.

Our results suggest that exogenous MLT provides effective free-radical scavenging in the cerebral cortex of rats. One-week-long MLT treatment, however, seems insufficient to decrease neuronal or glial apoptosis mediated by caspase-3.

The study was carried out in accordance with the internationly accepted ethical principles.

The authors, K. G. Akbulut, S. Guney, F. Cetin, H. N. Akgun, S. H. Aktas, and H. Akbulut, declare that there is no conflict of interests among them. 
К. Г. Акбулут ${ }^{1}$, С. Гуней ${ }^{1}$, Ф. Цетін ${ }^{1}$, Х. Н. Акгун С. Х. Акташ ${ }^{2}$, Х. Акбулут ${ }^{2}$

\section{МЕЛАТОНІН ЗАТРИМУЕ СТАРІННЯ МОЗКУ} ЗА РАХУНОК ЗНИЖЕННЯ РІВНЯ ОКСИДУ АЗОТУ

\author{
${ }^{1}$ Медичний університет Гази (відділ фізіології), Анкара \\ (Туреччина). \\ ${ }^{2}$ Медичний університет Анкари (відділ медичної \\ онкології), Анкара (Туреччина).
}

P е 3 ю м е

В аспекті розвитку нейродегенеративних розладів старіння розглядається як фактор ризику першого порядку. Втрату нервових клітин, яка відбувається з віком, пов'язували, в усякому разі частково, зі збільшенням продукції оксиду азоту та високій активності каспаз. Мелатонін (МТ) може відігравати певну роль у регуляції рівня оксиду азоту в мозку. Ми досліджували впливи МТ на рівні нітритів/нитратів та ензиматичну активність каспази-3 у фронтальній і темпоральній корі та гіпокампі молодих і старих щурів. Істотних відмінностей між рівнями нітритів у фронтальній корі та гіпокампі молодих і старих тварин виявлено не було, проте цей рівень в темпоральній корі старих тварин був істотно вищим $(P<0.001)$. У групі старих щурів МТ істотно знижував рівні нітритів в структурах мозку. Активність каспази-3 у фронтальних і темпоральних зонах кори старих щурів була достовірно вище, ніж у контрольних тварин $(P<0.05)$. Мелатонін не викликав істотних змін активності каспази-3 у всіх досліджених структурах мозку як молодих, так і старих щурів. Отже, рівні активності каспази-3 та концентрації нітритів в різних структурах мозку в перебігу процесу старіння демонструють певну специфічність. Вплив екзогенного МТ, мабуть, затримує старіння мозку (зменшуючи інтенсивність загибелі нейронів і глії) за рахунок зниження рівнів нітриту.

\section{REFERENCES}

1. R. A. Floyd and K. Hensley, "Oxidative stress in brain aging. Implications for therapeutics of neurodegenerative diseases," Neurobiol. Aging, 23, No. 5, 795-807 (2002).

2. X. H. Deng, G. Bertini, Y. Z. Xu, et al., "Cytokine-induced activation of glial cells in the mouse brain is enhanced at an advanced age," Neuroscience, 141, No. 2, 645-661 (2006).

3. I. Rozovsky, C. E. Finch, and T. E. Morgan, "Age-related activation of microglia and astrocytes: in vitro studies show persistent phenotypes of aging, increased proliferation, and resistance to down-regulation," Neurobiol. Aging, 19, No. 1, 97-103 (1998).

4. R. E. Mrak and W. S. Griffin, "Glia and their cytokines in progression of neurodegeneration," Neurobiol. Aging, 26, No. 3, 349-354 (2005).

5. M. P. Mattson, "Apoptosis in neurodegenerative disorders," Nat. Rev. Mol. Cell. Biol., 1, No. 2, 120-129 (2000).

6. M. P. Mattson, "Neuronal life-and-death signaling, apoptosis, and neurodegenerative disorders," Antioxid. Redox Signal., 8, Nos. 11/12, 1997-2006 (2006).
7. R. M. Friedlander, "Apoptosis and caspases in neurodegenerative diseases," New Engl. J. Med., 348, No. 14, 1365-1375 (2003).

8. C. M. Troy and G. S. Salvesen, "Caspases in the brain," J. Neurosci. Res., 69, No. 2, 145-150 (2002).

9. S. M. McCann, "The nitric oxide hypothesis of brain aging," Exp. Gerontol., 32, Nos. 4/5, 431-440 (1997).

10. A. Navarro and A. Boveris, "Mitochondrial nitric oxide synthase, mitochondrial brain dysfunction in aging, and mitochondria-targeted antioxidants," Adv. Drug. Deliv. Rev., 60, 1534-1544 (2008).

11. P. K. Kim, Y. G. Kwon, H. T. Chung, and Y. M. Kim, "Regulation of caspases by nitric oxide," Ann. New York Acad. Sci., 962, 42-52 (2002).

12. J. Sastre, F. V. Pallardó, and J. Viña, "Mitochondrial oxidative stress plays a key role in aging and apoptosis," IUBMB Life, 49, No. 5, 427-435 (2000).

13. M. E. Götz, E. Ahlbom, B. Zhivotovsky, et al., "Radical scavenging compound J 811 inhibits hydrogen peroxideinduced death of cerebellar granule cells," J. Neurosci. Res., 56, No. 4, 420-426 (1999).

14. A. M. Stranahan and M. P. Mattson, "Recruiting adaptive cellular stress responses for successful brain ageing," Nat. Rev. Neurosci., 13, No. 3, 209-216 (2012).

15. M. Tajes Orduña, C. Pelegrí Gabalda, J. Vilaplana Hortensi, et al., "An evaluation of the neuroprotective effects of melatonin in an in vitro experimental model of age-induced neuronal apoptosis," J. Pineal Res., 46, No. 3, 262-267 (2009).

16. Y. Hong, K. J. Palaksha, K. Park, et al., "Melatonin plus exercise-based neurorehabilitative therapy for spinal cord injury," J. Pineal Res., 49, No. 3, 201-209 (2010).

17. A. Leja-Szpak, J. Jaworek, P. Pierzchalski, and R. J. Reiter, "Melatonin induces pro-apoptotic signaling pathway in human pancreatic carcinoma cells (PANC-1),"J. Pineal Res., 49, No. 3, 248-255 (2010).

18. R. Hardeland, D. X. Tan, and R. J. Reiter, "Kynuramines, metabolites of melatonin and other indoles: the resurrection of an almost forgotten class of biogenic amines," J. Pineal Res., 47, No. 2, 109-126 (2009).

19. K. G. Akbulut, B. Gonul, and H. Akbulut, "Exogenous melatonin decreases age-induced lipid peroxidation in the brain," Brain Res., 1238, 31-35 (2008).

20. A. R. Meki, D. Esmail Eel, A. A. Hussein, and H. M. Hassanein, "Caspase-3 and heat shock protein-70 in rat liver treated with aflatoxin B1: effect of melatonin," Toxicon, 43, No. 1, 93-100 (2004).

21. L. Casciola-Rosen, D. W. Nicholson, T. Chong, et al., "Apopain/CPP32 cleaves proteins that are essential for cellular repair: a fundamental principle of apoptotic death," J. Exp. Med., 183, No. 5, 1957-1964 (1996).

22. K. M. Miranda, M. G. Espey, and D. A. Wink, “A rapid, simple spectrophotometric method for simultaneous detection of nitrate and nitrite," Nitric Oxide, 5, No. 1, 62-71 (2001).

23. A. M. Lynch and M. A. Lynch, "The age-related increase in IL-1 type I receptor in rat hippocampus is coupled with an increase in caspase-3 activation," Eur. J. Neurosci., 15, No. 11, 1779-1788 (2002).

24. M. K. Lucin and T. Wyss-Coray, "Immune activation in brain aging and neurodegeneration: too much or too little?" Neuron, 64, No. 1, 110-122 (2009).

25. G. E. Landreth, "Microglia in central nervous system diseases," J. Neuroimmune Pharmacol., 4, No. 4, 369-370 (2009).

26. J. P. Godbout and R. W. Johnson, "Age and neuroinflammation: 
a lifetime of psychoneuroimmune consequences," Immunol. Allergy Clin. North Am., 29, No. 2, 321-337 (2009).

27. E. Siles, E. Martínez-Lara, A. Cañuelo, et al., "Age-related changes of the nitric oxide system in the rat brain," Brain Res., 956, No. 2, 385-392 (2002).

28. A. Law, S. Doré, S. Blackshaw, et al., "Alteration of expression levels of neuronal nitric oxide synthase and haem oxygenase- 2 messenger RNA in the hippocampi and cortices of young adult and aged cognitively unimpaired and impaired Long-Evans rats," Neuroscience, 100, No. 4, 769-775 (2000).

29. D. Vernet, J. J. Bonavera, R. S. Swerdloff, et al., "Spontaneous expression of inducible nitric oxide synthase in the hypothalamus and other brain regions of aging rats," Endocrinology, 139, No. 7, 3254-3261 (1998).

30. P. Liu, Y. Jing, and H. Zhang, "Age-related changes in arginine and its metabolites in memory-associated brain structures," Neuroscience, 164, No. 2, 611-628 (2009).

31. S. Blanco, F. J. Molina, L. Castro, et al., "Study of the nitric oxide system in the rat cerebellum during aging," BMC Neurosci., 11, 78 (2010).

32. C. Hutton, B. Draganski, J. Ashburner, and N. Weiskopf, "A comparison between voxel-based cortical thickness and voxel-based morphometry in normal aging," Neuroimage, 48, No. 2, 371-380 (2009).
33. A. Schuitemaker, T. F. van der Doef, R. Boellaard, et al., "Microglial activation in healthy aging," Neurobiol. Aging, 33, No. 6, 1067-1072 (2012).

34. X. G. Luo, J. Q. Ding, and S. D. Chen, "Microglia in the aging brain: relevance to neurodegeneration," Mol. Neurodegener., 5, $12(2010)$.

35. A. Das, A. Belagodu, R. J. Reiter, et al., "Cytoprotective effects of melatonin on $\mathrm{C} 6$ astroglial cells exposed to glutamate excitotoxicity and oxidative stress," J. Pineal Res., 45, No. 2, 117-124 (2008).

36. K. G. Akbulut, H. Akbulut, N. Akgun, and B. Gonul, "Melatonin decreases apoptosis in gastric mucosa during aging," Aging Clin. Exp. Res., 24, No. 1, 15-20 (2012).

37. Y. Zhang, E. Chong, and B. Herman, "Age-associated increases in the activity of multiple caspases in Fisher 344 rat organs," Exp. Gerontol., 37, No. 6, 777-789 (2002).

38. A. Zhang, D. E. Lorke, S. X. Wu, and D.T. Yew, "Caspase-3 immunoreactivity in different cortical areas of young and aging macaque (Macaca mulatta) monkeys," Neurosignals, 15, No. 2, 64-73 (2007).

39. J. Chetsawang, P. Govitrapong, and B. Chetsawang, "Melatonin inhibits MPP+-induced caspase-mediated death pathway and DNA fragmentation factor-45 cleavage in SK-N-SH cultured cells," J. Pineal Res., 43, No. 2, 115-120 (2007). 